\title{
構造ヘルスモニタリングのための 慣性センシングによる傾斜・振動計測法
}

\author{
杉崎 光一 1 阿部 雅人 $2 \cdot$ 輿水 聡 3 \\ 1正会員＼cjkstart株式会社BMC（テ261-7125 千葉市美浜区中瀬2-6 WBGマリブウエスト25階） \\ E-mail: sugisaki@hashimori.jp \\ 2正会員 株式会社BMC 主幹研究員（†261-7125 千葉市美浜区中瀬2-6 WBGマリブウエスト25階） \\ E-mail: masato@hashimori.jp \\ 3正会員ＪR東日本防災研究所（广331-8513 埼玉県さいたま市北区日進町二丁目479番地） \\ E-mail: koshimizu@jreast.co.jp
}

\begin{abstract}
構造物の実用的なモニタリング手法の開発では，計測が容易である慣性計測を有効に利用していく必要 がある。しかし，慣性計測は重力を検知する方法であるため，加速度を検知する場合はセンサが傾斜する ことで，また，傾斜を検知する場合は加速度による誤差が生じる。これを測定誤差として許容してしまう と, 低振動数域において誤差は大きく拡大されるため, 変位等に変換する際には大きな問題となる. 本研 究では, 慣性センサの補正方法について理論を構築し, いくつかの構造系を特定し補正の際のパラメータ の求め方を示す，特に，単柱橋脚では，簡易なフィル夕処理により補正が可能であることを示し，実際の 鉄道橋梁の単柱橋脚の天端に設置された慣性センサの列車通過時の応答を利用して，別途計測する変位計 との比較から手法の有効性を検証する.
\end{abstract}

Key Words : inertial sensing, accelerometer, clinometers, health monitoring

\section{1. はじめに}

構造物の維持管理において，外力に対する応答を計測 することは，性能を知る上で大変重要である．近年では, センサの精度や測定範囲の向上により, 様々な応答を計 測することが可能となってきた1).このため, 様々な物理 量を計測することで, 総合的に構造物の性能を評価しよ うというコンセプトが，構造物のヘルスモニタリングに おいては提案されている2の。 、ヘルスモニタリングにおけ るセンサの選定条件としては, 汎用化のためには安価で あること，また設置が容易であることが重要となる，設 置の容易性を考えた場合, 加速度や傾斜といった慣性計 測が考えられる. 慣性計測は, 空間的な位置情報を必要 としない自立式の計測装置による計測である。 それに対 して, 変位計測では, 一般的に固定点が必要であり, 計 測が困難である.このため, 慣性計測により計測した加 速度を, 構造物の性能をよく表す変位へ変換する方法が 提案されているれの。

慣性計測に利用する加速度センサの原理は，「振子」 や「ばね」にかかる慣性力の大きさを加速度として検知 するものである゙?. 文献9)では, 加速度センサを利用して
鉄道構造物の性能評価をモニタリングする上で, センサ に要求される性能を表-1のように整理している.このよ うな仕様を満たすような加速度センサでは, 特にDC值の 安定性や低ドリフトに対して，センサが傾斜することに より受ける重力加速度の影響があり，その他の外乱から の加速度の影響とを原理的に分離することが困難であ る 8100111)。この問題を克服するために, 他分野では, 加速 度と角速度の同時計測を行い, センサの姿勢を検知して

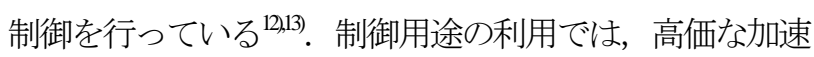
度計を利用しており，また角速度の計測においても高価 なジャイロ技術を利用している. 地震計の設置において も，センサが傾いて設置されることによる計測誤差が指 摘されており，傾斜量を計測し補正する方法が検討され ている ${ }^{14,15)}$ ここのように, 慣性計測においては, 加速度セ ンサが計測時に傾斜する影響を把握することが重要と考 えられている.

構造物の計測においては，加速度計測における傾斜の 影響は，傾斜が微小であることもあり，センサの計測誤 差（低振動数域のセンサ自己ノイズや温度特性による基 線ずれての) や解析の積分誤差等として認識されてきた. 加速度センサが構造物と共に挙動し傾斜すると, 水平加 
表-1 センサ評価項目（AD変換を含む） $\left.{ }^{9}\right)$

\begin{tabular}{c|l}
\hline \multirow{2}{*}{ 要求性能 } & \multicolumn{1}{c}{$\begin{array}{c}\text { センサ性能 } \\
\text { (加速度・傾斜センサ) }\end{array}$} \\
\hline \multirow{2}{*}{ 傾斜計測 } & $\begin{array}{l}\text { DC 温度特性の安定性 (感 } \\
\text { 度, ゼロ点不均衡) }\end{array}$ \\
\cline { 2 - 2 } & 低ドリフト \\
\hline \multirow{2}{*}{ 長期性能 } & 而久久性 \\
\cline { 2 - 2 } センサ特性の安定性 & ゼイス \\
\hline \multirow{2}{*}{ 微動計測 } & 低自己ノイズ \\
\cline { 2 - 2 } 列車応答計測 & 高解像度 \\
\hline
\end{tabular}

速度の検出においては重力加速度の影響を受ける.この 問題は，加速度を計測するという観点からはあまり問題 とならないが, 加速度応答から変位を算出するする際に は, 推定精度に致命的な影響を与える. このため, 機械 的な影響に関しては可能な限り除去することが必要であ る.

本研究の構成を以下に述べる. 2.では, 慣性センサの 原理から重力加速度の影響を述へ，加速度と傾斜を分離 する必要性について整理を行う．3.では，簡易物理モデ ルを定義し加速度と傾斜の相互の影響について整理する， 4.においては，加速度と傾斜の関係を捉えるためのパラ メータを定義し，その物理的な意味について検討し，算 定方法を提案する. 5.において, 実際のデータを利用し て提案するモデルの有効性を検証する．6.において結論 を述べる。

\section{2. 慣性計測における重力の影響}

慣性計測は，航空機やロケットの誘導方法等，慣性航 法装置（Inertial Navigation System: INS）として一般的なもの であり, ロボット工学や測量等にも応用されている. 慣 性計測の種類としては表-2に示すようなものがある. 近 年 MEMS(Miro Electro Mechanial Systems)センサが開発され, 高精度, 広帯域, 小型かつ安価で利用できるようになっ ている. 加速度を計測するセンサ原理は，「振り子」や 「ばね」を利用したものであり，例えば MEMS センサに おいては，振動するセンサ躯体と不動点となる重りで構 成され，そのギャップ $(x)$ を静電容量や圧力の変化から 捉え, 運動方程式 $(k x=m a)$ から加速度を求めるものである. 土木用途としては, 地震センサや鉄道における軌道管理 等で利用されている. 慣性計測用の加速度センサでは, 重力以外の外乱による加速度が生じていない場合では,

図-1のようにセンサを傾斜させたときに検出する加速度 を $a$ とし, 重力加速度を $g$ とすれば

$$
\theta=\arcsin \left(\frac{a}{g}\right)
$$

により，重力加速度を利用して傾斜を求めることもでき る. 対して, 重力以外の外乱が生じている場合は, 重力 加速度と相対的に生じている加速度とを原理的に分離す ることができない，このため式(1)を利用して単純に傾斜 角を計測することができない. このため，一般的にジャ イロを利用して角速度を同時に計測し，姿勢等の制御を 行う方法が利用されている.

角速度を計測するジャイロの原理としては, 特に MEMS センサにおいては，コリオリの力を利用するのが 一般的である. 回転している物体において，センサに内 蔵されたアクチュエータで質量 $m$ の構造体を速度 $v$ で励 振し, 生じたコリオリ力 $(2 m v \omega)$ をピエゾ抵抗, 静電容 量, 圧電効果等を利用して計測できれば，角速度 $\omega$ を求 めることが可能となる. 角速度を求めることができれば, 積分を一回寸れば角度を求めることができる. ただし， ジャイロ計測の問題点としては, 航空機等の高速で動い ているもの，またロボット等のように回転角が大きい場 合は精度がよくなるが，低速や回転が少ない場合は，角 速度の測定誤差や, 角度を求める際の積分誤差等が大き くなることが知られている，地震センサにおいては，回 転成分の検出等の目的で，ジャイロ技術を利用した同時 計測方法が検討されていたが沾，固定式のみでなく，ケー ブル式の地震計でも大きく傾斜することが無いとの報告

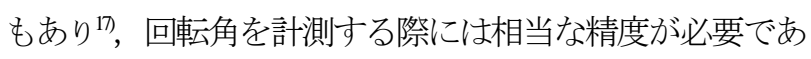
ると考えられる. しかし，レーザージャイロのような高 精度のものは大変高価あり, 安価で精度のよいジャイロ の開発は行われているが，より実用的な方法として，加 速度計を併用したり, 加速度計測のみから姿勢を検知す る方法も検討されている ${ }^{18}$.

構造物の計測においては, 構造物の諸元により大きさ は相違するが，地盤等における計測よりも大きな角速度 が生じる可能性が考えられる. ジャイロを利用し構造物 の応答を評価した研究としては, 鈴木らの研究がある ${ }^{19}$. 大型振動台による振動実験において，建物にジャイロを 設置し求めた角速度と, 同時に変位計測を行い, ねじれ 振動が卓越する構造において, 角速度と相対変位に相関 がみられることを示している，これにより，被嗐評価な どに利用できる可能性を示している，ただし，角速度が 小さい破壊の初期の段階においては，ジャイロにおける 自己ノイズが高いため, 安価なジャイロを利用すること は困難としている.

ジャイロではなく, 傾斜角を計測する方法としては, 水準器の原理を利用した傾斜センサを利用する方法が考 えられる. 原理としては, センサが傾斜した際の重力に 
表-2 慣性計測

\begin{tabular}{c|c|c}
\hline 算出物理量 & 測定物理量 & 原理 \\
\hline \hline 加速度 & 加速度 & $\begin{array}{c}\text { 運動方程式 } \\
\text { (振り子, ばね })\end{array}$ \\
\hline 傾斜角 & 重力加速度 & $\begin{array}{c}\text { 式(1) } \\
\text { 角速度 }\end{array}$ \\
\hline 角速度 & $\begin{array}{c}\text { こま, サニヤツク効果, } \\
\text { コリオリカ }\end{array}$ \\
\hline 傾斜角 & 加速度 & 式(1) \\
\hline
\end{tabular}

図-1 加速度計における重力の影響

よる気泡の動きから，傾斜を求める方法である. 重力加 速度を利用した計測であるから，傾斜以外の外乱による 加速度が生じている場合は，当然加速度の影響を受ける. 加速度の影響としては，水平方向から加速度 $a$ が生じる 時には，傾斜が無い場合でも以下の の傾斜角を観測する ことになる.

$$
\hat{\theta}=\arctan \left(\frac{a}{g}\right)
$$

ただし，気泡は加速度に対して粘性等による次遅れ等 の影響があるため，式(2)の值が正確に生じるわけではな い. ただし，水準器の原理を利用した傾斜計は，安価な ものでも分解能を小さくできる利点があり，傾斜角を直 接計測しているため, ジャイロのような角速度を積分す る必要がなく, 微小な傾斜を計測する場合には有効であ る. そのため，動的な計測において，傾斜計測に含まれ る加速度の影響を分離することは傾斜計を利用したモニ タリングの実用化に向けて大変有用である.

\section{3. 簡易物理モデル}

\section{(1) 基礎理論}

慣性計測において加速度と傾斜角を分離するための基 礎理論を述べる. 図-2のような座標軸を定義し， $\theta$ : 傾斜 角, $x$ :変位, $\ddot{x}, \ddot{y}$ : 加速度のように定義する. $g$ は重 力加速度である. 図-2 のようにセンサを設置した場合, センサは傾斜し慣性力の影響を受け，応答傾斜角 $\theta^{\prime}$ ，応 答加速度 $\ddot{X}^{\prime}$ とすると以下のような物理量が計測されるこ とになる。

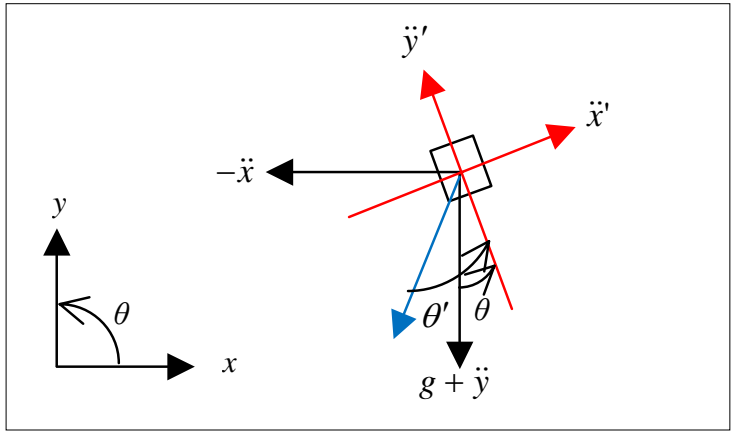

図-2 座標系

$$
\begin{gathered}
\theta^{\prime}=\arctan \frac{\ddot{x}}{(-g-\ddot{y})}+\theta \\
\ddot{x}^{\prime}=\ddot{x} \cos \theta+(\ddot{y}+g) \cos \left(\theta-\frac{\pi}{2}\right)
\end{gathered}
$$

ここで，2.で示した $a$ は将 の傾き $\theta=0$ の場合であり， $\hat{\theta}$ は $\theta^{\prime}$ の重力以外の加速度 $\ddot{x}=0$ の場合であることに注意 されたい.

$\theta$ は微小であると考えると，それぞれの式は,

$$
\begin{gathered}
\theta^{\prime}=\frac{-\ddot{x}}{g+\ddot{y}}+\theta \\
\ddot{x}^{\prime}=\ddot{x} \cos \theta+(\ddot{y}+g)(\sin \theta) \\
=\ddot{x}+(\ddot{y}+g) \theta
\end{gathered}
$$

となる. $g \gg \ddot{y}$ とすると

$$
\begin{aligned}
& \theta^{\prime}=\frac{-\ddot{x}}{g}+\theta \\
& \ddot{x}^{\prime}=\ddot{x}+g \theta
\end{aligned}
$$

となる．両辺をフーリエ変換すると，

$$
\begin{gathered}
\Theta^{\prime}=\frac{\omega^{2} X}{g}+\Theta \\
\ddot{X}^{\prime}=\ddot{X}+g \Theta
\end{gathered}
$$

である。

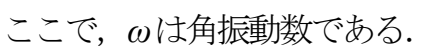

\section{（2）加速度および傾斜角の補正}

弾性体の振動を考えた場合，任意点 $\xi$ のる時刻 $\tau$ にお ける変位 $x(\xi, \tau)$ と傾斜角 $\theta(\xi, \tau)$ はそれぞれの座標関数を $Y(\xi)$, $Z(\xi)$ とし，時間関数 $q(\tau)$ とすれば，以下のように表わすこ とができる。

$$
\begin{aligned}
& x(\xi, \tau)=Y(\xi) \cdot q(\tau) \\
& \theta(\xi, \tau)=Z(\xi) \cdot q(\tau)
\end{aligned}
$$

座標関数における固有振動モードを $Y_{n}, Z_{n}(n=1,2, \ldots, N)$ と考え，ある固有モード $k$ に着目すれば，両者の関係は 線形関係であり， 


$$
\frac{x}{\theta}=\frac{Y_{k}}{Z_{k}}=\delta
$$

となる.ここで， $\delta$ は座標関数によって決まる係数であ

り，長さの単位を持つものである．この仮定は弾性体で あることに加え，以下のような場合に成り立つと考えら れる.

・ $x, \theta$ ガ拘束されていないこと

・荷重の載荷条件が変わらないこと

1番目の仮定に関しては，支点や岡結点等による拘束がな いことを想定しており，センサの設置場所を考慮するこ とで成り立つと考えられるが，2番目の仮定については， 実際の現象において成り立つかは常に考慮が必要である. 式(8)を利用することで式(6)を以下のように変形できる.

$$
\begin{aligned}
& \Theta^{\prime}=\left(1+\frac{\omega^{2} \delta}{g}\right) \Theta \\
& \ddot{X}^{\prime}=\left(1+\frac{g}{\delta \omega^{2}}\right) \ddot{X}
\end{aligned}
$$

$$
\omega_{c}=\sqrt{\frac{g}{\delta}} \text { とすると, }
$$

$$
\begin{aligned}
& \Theta=\frac{\Theta^{\prime}}{\left\{1+\left(\frac{\omega}{\omega_{c}}\right)^{2}\right\}} \\
& \ddot{X}=\frac{\ddot{X}^{\prime}}{\left\{1+\left(\frac{\omega_{c}}{\omega}\right)^{2}\right\}}
\end{aligned}
$$

となる. このように， $\theta^{\prime}$ から $\theta, \ddot{x}^{\prime}$ から $\ddot{x}$ を求めること が可能である.また，同様に，

$$
\begin{gathered}
\Theta^{\prime}=\frac{\ddot{X}}{g}+\frac{\ddot{X}}{\omega^{2} \delta} \\
\ddot{X}^{\prime}=\delta \omega^{2} \Theta+g \Theta
\end{gathered}
$$

となり，

$$
\begin{aligned}
& \ddot{X}=\frac{\Theta^{\prime}}{\left(\frac{1}{g}+\frac{1}{\omega^{2} \delta}\right)} \\
& \Theta=\frac{1}{\left(\delta \omega^{2}+g\right)} \ddot{X}^{\prime}
\end{aligned}
$$

であるから $\theta^{\prime}$ から $\ddot{x} ， \ddot{x}^{\prime}$ から $\theta$ を求めることも可能であ る.

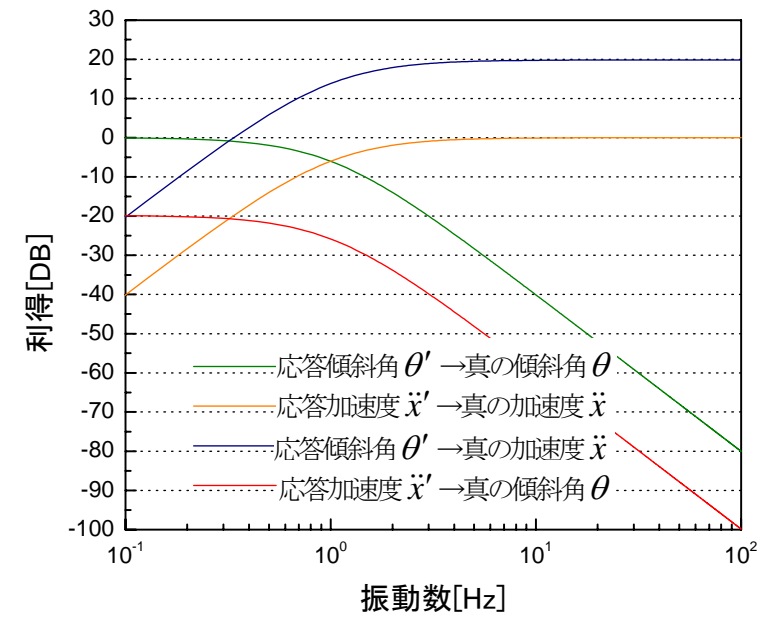

図-3 フィルタの利得

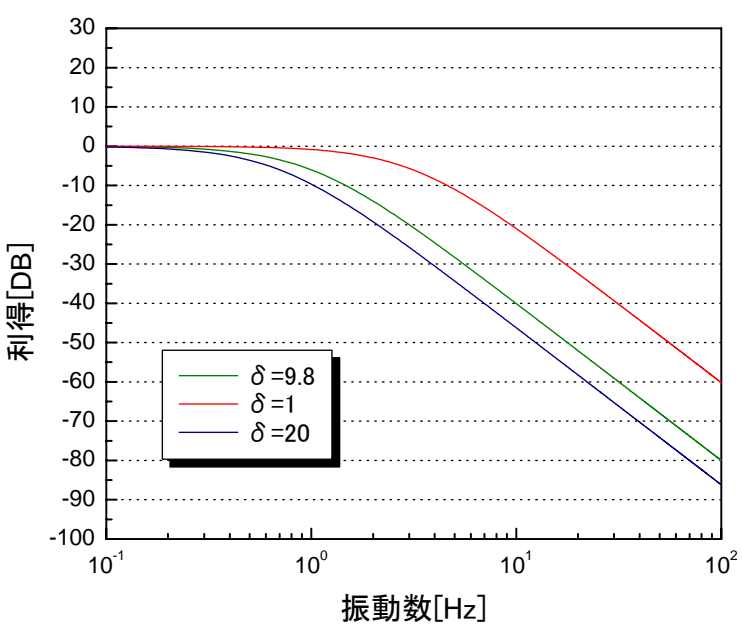

図-4 $\delta$ と利得の関係（傾斜計の加速度補正フィルタ）

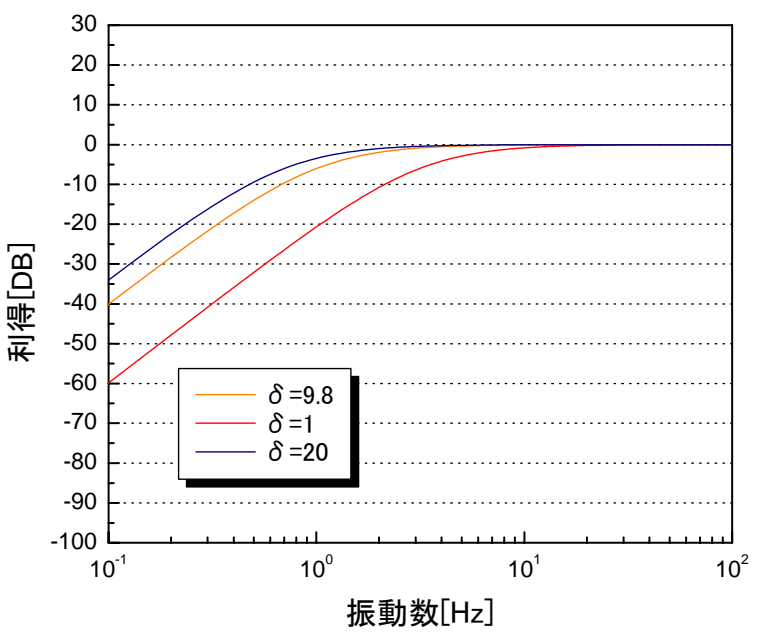

図-5 $\delta$ と利得の関係 (加速度計の傾斜補正フィルタ)

\section{(3) 数值例}

式(8)について，例えば $\delta=9.8(\mathrm{~m})$ として，振動数ごとにそ れぞれ利得として $\Theta / \Theta^{\prime}$ および $\ddot{X} / \ddot{X}^{\prime}$ をプロットするこ とでフィルタ特性を求めることができる.フィルタ特性 
を求めた結果を図-3に示寸.このフィルタは 2 次のバタ ーワース型のローパスおよびハイパスフィルタとなって いる. 同様に, $\ddot{X} / \Theta^{\prime}, \Theta / \ddot{X}^{\prime}$ からもフィルタを求める ことができる，結果を図-3に示寸，また， $\delta$ の目安を示寸 ために, 一般的な土木構造物における目安として，1(m) および 20(m)とした場合の $\Theta / \Theta^{\prime}$ および イルタ特性の変化を図-4, 図-5に示寸。これらのフィルタ が利用可能であるかは, センサの計測可能な振動数範囲 により決まる.

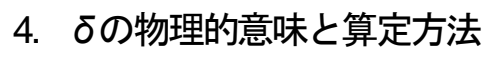

本手法を適用する際には，式(8)で定義したパラメータ $\delta$ を求めることが必要となる. $\delta$ は物理的な意味を有してい るため, まずは, 既往の研究等から $\delta$ の物理的な意味に ついて検討を行う. その後に, $\delta$ 求め方を検討する.

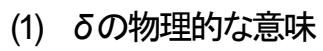

中村らは, 橋脚のロッキング振動における水平反力の 作用位置としてのロッキング中心と有効な根入れ長との 関係加構造物の健全性を評価する方法を提案している゙の). 測点からロッキング中心までの距離 $L$ を定義すれば，本 手法との関係は， $\delta=L$ となる. また, 文献19)では, 1 層 に耐震壁が偏在して配置される偏心ピロティ構造におけ るねじれ振動について，並進と回転が練成するモデルの 相対変位と角度の関係を求め, 高次モードを無視するこ とで， $\delta$ が定数になることを求めている． $\delta$ は回転中心の 移動などを表すことから，柱の損傷等の変状を検知する ことができると考えられている. このように， $\delta$ 值を求 めることは構造物の健全度を評価する上でも大変有用と なる.

一般的に, 弾性体においては, 式(8)における座標関数 を与えることで, 構造系ごとに $\delta$ を定義することができ る. 例えば，スパン $L$ の片持ち梁の 1 次モードを考えた 場合は，片持ち梁の端部での $Y_{1}$ および $Z_{1}$ は以下である.

$$
\begin{aligned}
& Y_{1}=\frac{P L^{3}}{3 E I} \\
& Z_{1}=\frac{P L^{2}}{2 E I}
\end{aligned}
$$

よって,

$$
\delta=\frac{Y_{1}}{Z_{1}}=\frac{2}{3} L
$$

と求めることができる.この関係は, 梁やラーメンとい った構造物においても文献21)等を利用して算出できるた め, $\delta$ の目安を与える. 文献19)では, 剛体の回転運動の 運動方程式から $\delta$ の值を算出している. また, 単柱橋脚
の回転運動を考えれば，回転中心半径が $\delta$ となる．単柱 橋却の事例については後述する。

\section{(2) $\delta$ 算定方法}

具体的な $\delta$ を実際の計測を利用して求める方法は, 計 測条件によって異なる. 計測条件は，固定計測を行うこ とができる場合と慣性計測のみしかできない場合で大き く相違する. 固定計測ができる場合は, 図-2に示したセ ンサの応答加速度 $\ddot{x}^{\prime}$, 応答傾斜角 $\theta^{\prime}$ の慣性計測以外に, 固定計測（変位計測等）により $x$ を求めることでその関 係から $\delta$ を求めることができる.

それに対して，慣性計測のみ（傾斜と加速度の両方を 計測）から求める方法は，より実用的な方法と考えられ るが，特性の相違するセンサによる複数の慣性計測結果 を利用することが考えられる．慣性計測結果を傾斜に換 算する場合，式(9a)と式(12b)に示したように， $\delta$ が大きけ れば，ローパスフィルタのカットオフ振動数が下がり， $\delta$ が小さければ上がることになる。つまり, 傾斜計から求 めた傾斜と加速度計から求めた傾斜が合うように $\delta$ を決 定することで, 最適な $\delta$ を求めることができる. また, その他の方法として, 中村らは, ロッキング振動を行う 橋脚に対して，2方向の加速度計の応答を利用することで, 測点からロッキング中心までの距離 $L$ を求める方法を提 案している゙の. それによると, 水平振幅 $H$ と垂直振幅 $V$ から,

$$
L=B \frac{H}{V}
$$

となる.

ここで, $B:$ 橋脚の幅の $1 / 2$ である.

この方法は，常時微動を利用して行う方法であるため， 高感度なセンサを利用する必要がある。

\section{5. 現地試験による検証}

\section{(1) 計測概要}

対象橋脚は 1967 年に施工された杭基礎橋脚である. 橋 脚諸元については表-3にまとめる。部構造は，支間 $22.3 \mathrm{~m}$ の上路プレートガーダー形式の橋梁 8 連から成る. 本計測では， 1 号橋脚を対象とした。計測システムは, 列 車通過や地震による 5Gal 以上の加速度応答をトリガーと し，トリガー時刻の 30 秒前から 120 秒間の波形が記録さ れる. サンプリング周波数は $100 \mathrm{~Hz}$ である. 測定列車は 電車だけでなく貨物列車もあり, 列車速度にもばらつき がある、これは単線であることや駅が傍にあることが影 響している. 編成についても，4両編成を中心として，2 両，6両とあり，貨物列車も含め，列車編成は多様である. 


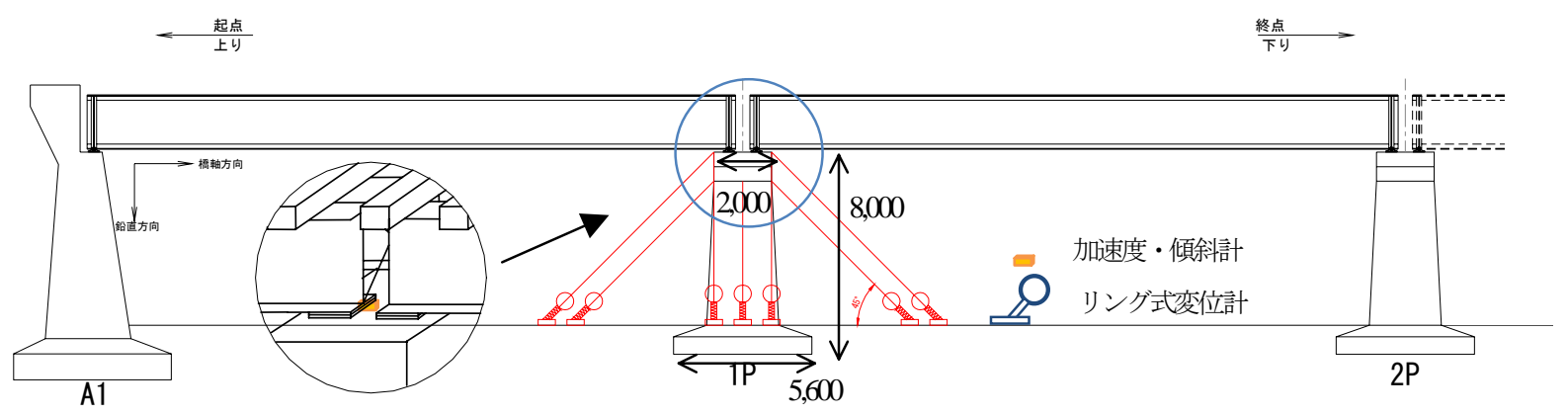

図6 測定概要図

表-3 橋梁諸元

\begin{tabular}{c|c}
\hline 諸元項目 & 内容 \\
\hline \hline 施工年 & 1967 年 \\
\hline 形式 & 杭基礎 \\
\hline 支間 & $22.3 \mathrm{~m}$ \\
\hline 材料 & 鉄筋コンクリート \\
\hline
\end{tabular}

表-4 加速度センサ性能

\begin{tabular}{c|c}
\hline 項目 & 性能 \\
\hline \hline 加速度分解能 & $0.2 \mathrm{Gal}$ \\
\hline 振動数帯域 & DC-20Hz \\
\hline 計測範囲 & $\pm 200 \mathrm{Gal}$ \\
\hline
\end{tabular}

表-5 傾斜センサ性能

\begin{tabular}{|c|c|}
\hline 項目 & 性能 \\
\hline 傾斜角分解能 & $2.5 / 1000$ deg \\
\hline 傾斜角計測範囲 & \pm 0.5 deg \\
\hline
\end{tabular}

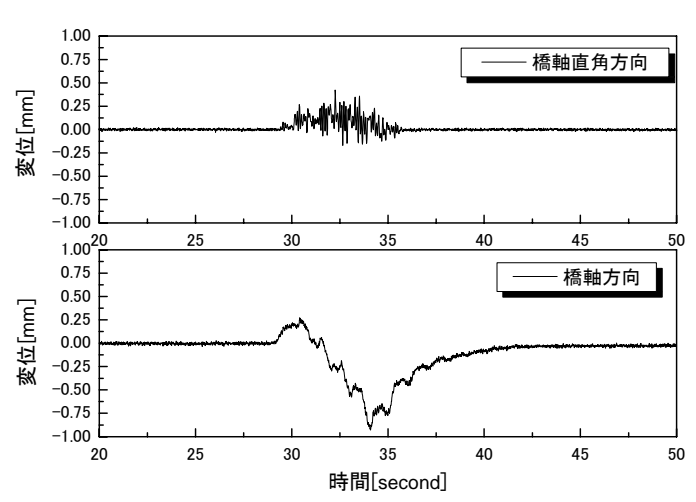

図-7 列車通過時の変位計応答 $x$

測定方法であるが，図-6に示寸ように，橋脚天端にリ ング式変位計を 8 本設置し, また, 橋脚首部にも 4 本設 置し，換算して橋脚の変位や傾斜を求めた．また合わせ て, 変位応答を 2 階微分することで加速度応答を求めた. 変位の換算方法については付録に示す。

また, 橋脚天端に慣性センサとして, 傾斜センサ水平 2 軸，および 3 軸加速度センサを設置した. 傾斜センサお よび加速度センサのメーカーの仕様による性能は, 表-4,

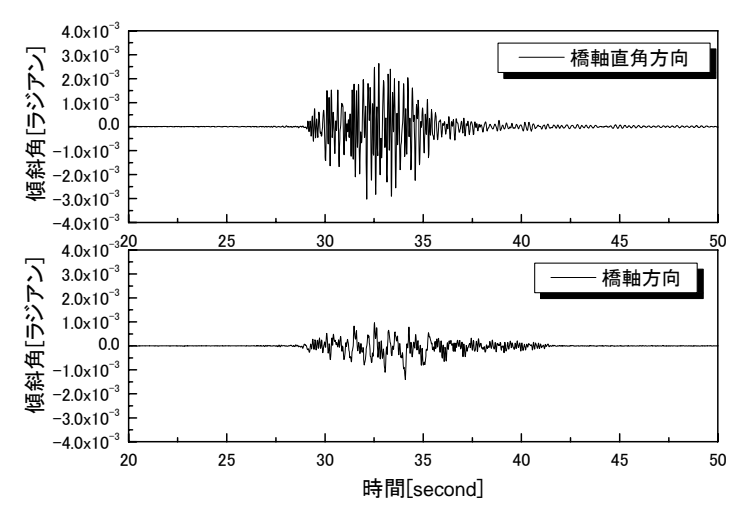

図-8 列車通過時の応答傾斜角 $\theta^{\prime}$

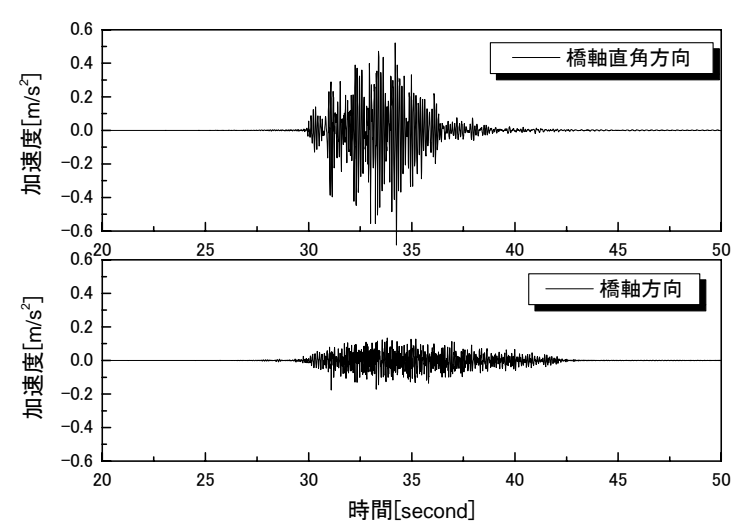

図-9 列車通過時の応答加速度 $\ddot{x}^{\prime}$

表-5に示寸通りである. 計測結果について, 列車通過時 の変位応答を図-7, 応答傾斜角を図-8, 応答加速度を図-9 に示寸が，傾斜応答については波形のみからでも加速度 の影響がみてとれる。

\section{(2) $\delta の$ 算出結果}

図-10に示寸ような橋脚のロッキング振動に対して $\delta$ を 算出した結果を以下に述べる.

\section{a) 固定計測ができる場合}

応答傾斜角のほかに水平変位を同時に計測しておけば, 4.で述べたように， $\delta$ を算出することが可能となる. 付録 に示した方法で, $\theta$ と $x$ を変位計から換算し $\delta$ を求めた結 果が図-11である。この值の妥当性を検討するために, 


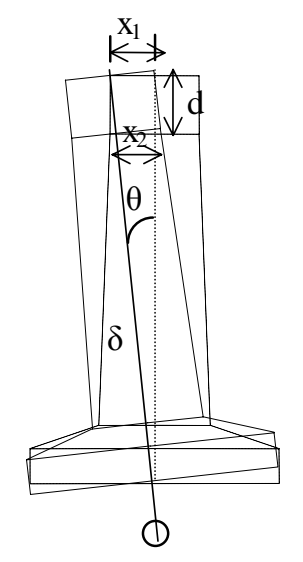

図-10 橋脚の回転運動

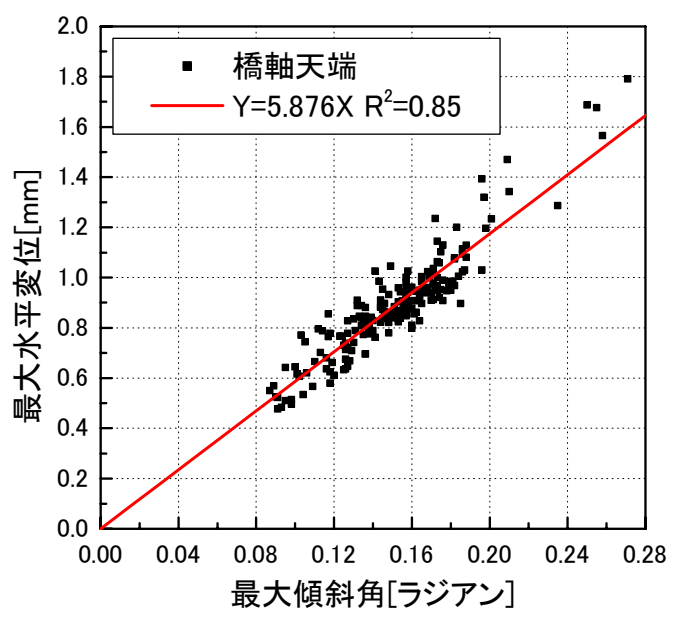

図-11 変位計との比較による $\delta$ 算出結果

図-10の $x_{1}$ と $x_{2}$ のように, 橋脚高さの違う位置で変位を求 めた結果から $\delta$ を算出した. 算出方法は, $\theta$ を一定とした 場合には，以下のように求めることができる.

$$
\begin{gathered}
\theta=\frac{x_{1}}{\delta}=\frac{x_{2}}{\delta-d} \\
\delta=\frac{d x_{1}}{\left(x_{1}-x_{2}\right)}
\end{gathered}
$$

ただし，dは既知である.

各列車ごとの $x_{1}$ の最大值と $x_{2}$ の最大值を利用して式(17) から $\delta$ を求めた結果が図-12である.この結果からも $\delta$ は 5 7 付近にあり, 図-11の結果である $\delta=5.9$ は, 妥当な值で あると言える。

\section{b) 慣性計測のみから求める場合}

a)において示したように，固定計測を行うことができ れば， $\delta=5.9$ を得る事が可能である. しかし，慣性計測の 从から $\delta$ を求めることができれば手法の適用範囲を広げ ることができる，そこで，応答加速度と応答傾斜角の関 係を利用して $\delta$ を算出寸る. 例えば，応答加速度と応答 傾斜角のスペクトル比から振動数ごとに $\delta$ を算出した結 果が図-13である。傾斜計では，前述したように高い振動 数帯では次遅れがあるため, 応答加速度に対して小さな

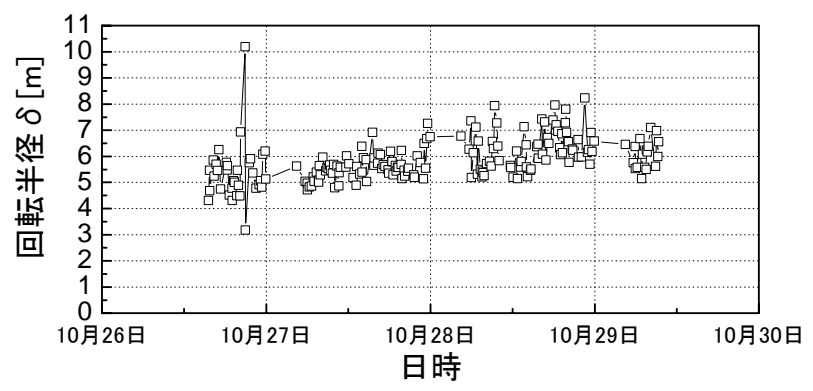

図-12 変位計との比較による $\delta$ 算出結果

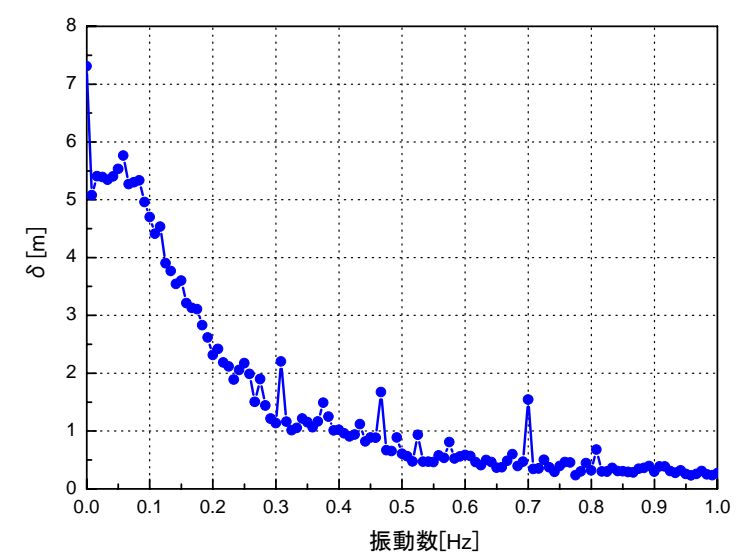

図-13加速度と傾斜のスペクトル比（橋軸）

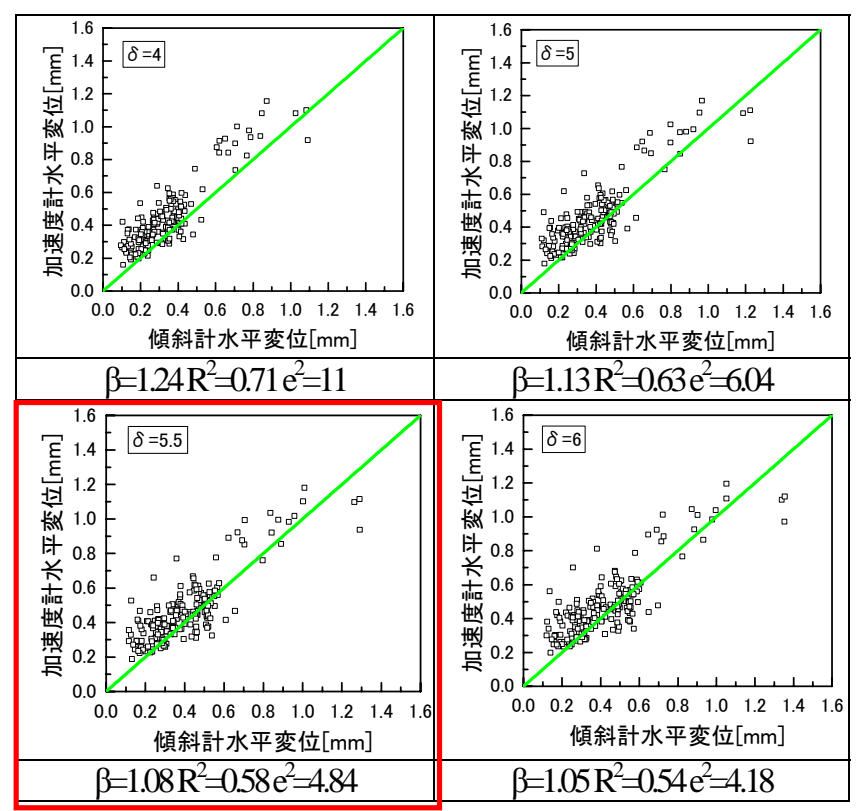

図-14 傾斜計と加速度計による $\delta$ 算定

值となりスペクトル比が小さくなっている．図-13の結果 からは，0.1Hzくらいまでは次遅れの影響が小さく, $0.1 \mathrm{~Hz}$ までの平均をとれば $\delta=5.5 \mathrm{~m}$ を得る. さらに, 複数の列車 通過時の波形が得られる場合は，図-14に示すように $\delta$ の 值を変化させながら，傾斜計から換算した変位と加速度 計から換算した変位の相関関係から $\delta$ を求めることがで きる. $\delta$ の推定結果の評価基準は, 回帰式の決定係数 $R^{2}$ や回帰係数 $\beta(y=\beta x)$ が 1 に近いこと, また誤差の 2 乗和 $e^{2}$ 

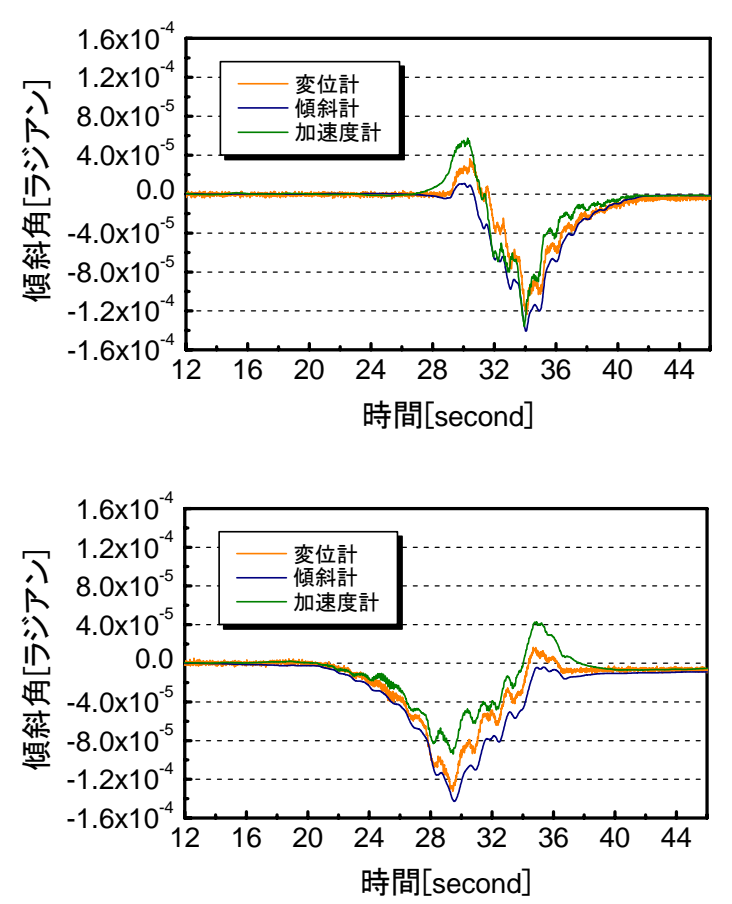

図-15 傾斜角 $\theta$ の波形比較(上 : 下り $70 \mathrm{kmh}$ 下: 上り $44 \mathrm{kmh}$ )
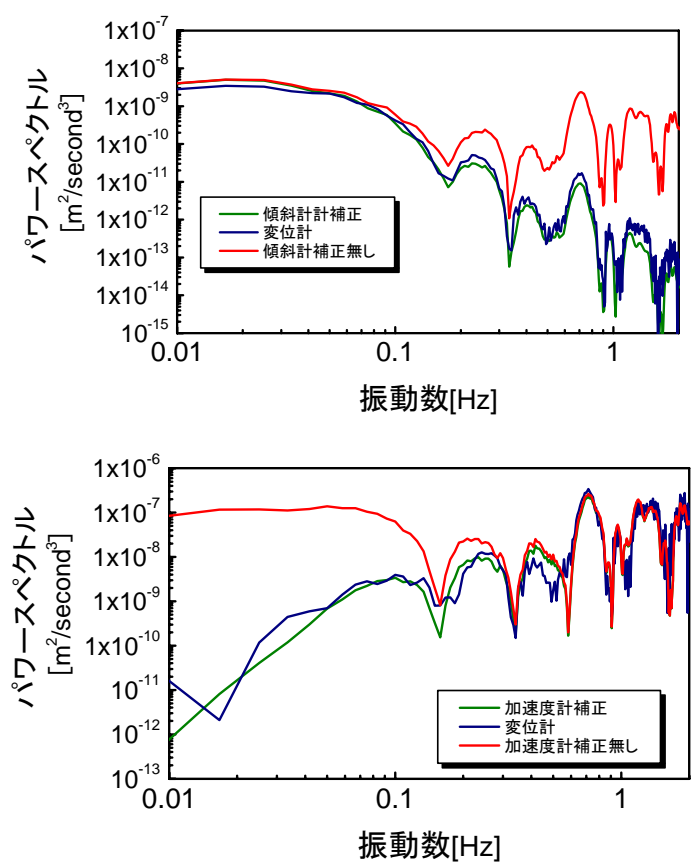

図-16 補正効果（上 : 傾斜計 下: 加速度計）

が小さいこと等から総合的に判断することになる.この 二つの結果から $\delta=5.5$ を採用することができ，その結果は 固定計測から求めた $\delta=5.9$ と整合的である.

\section{（3）応答加速度および応答傾斜角の補正結果}

$\delta$ を決めることができれば，式(10)を利用して傾斜セン サを補正し傾斜角を，式(12)を利用して加速度センサを補 正し傾斜角を求めることができる. $\delta$ 值については求め
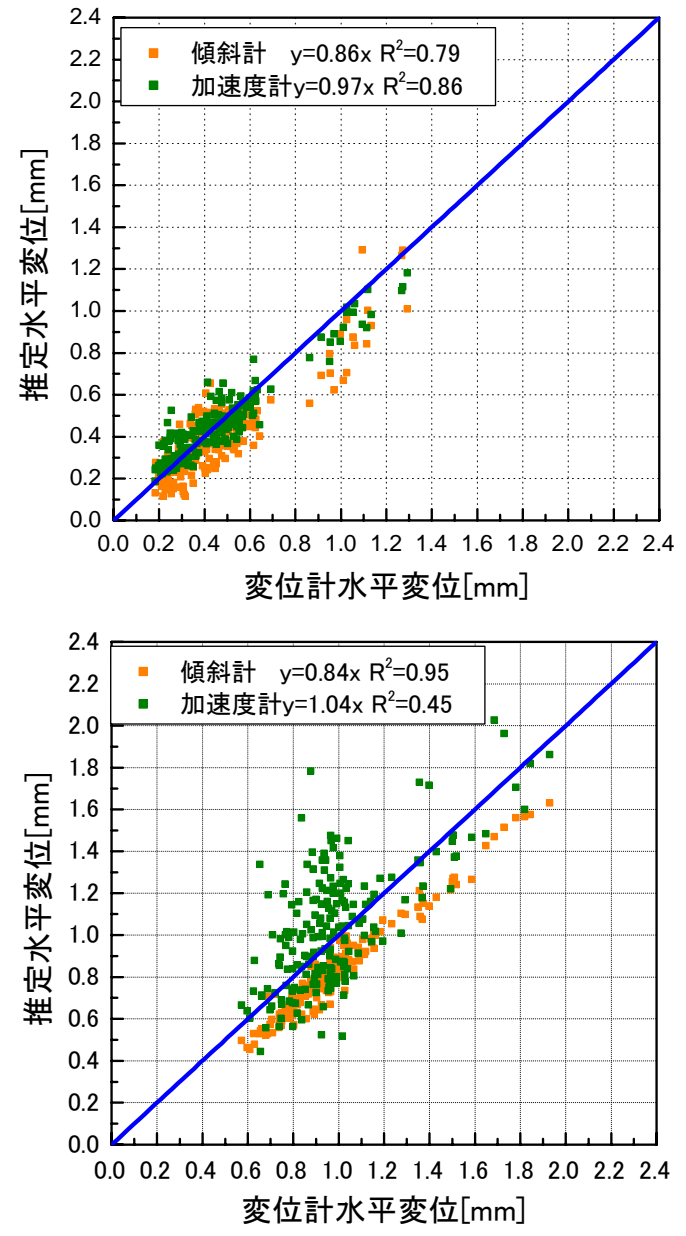

図-17 変位換算結果 (上 : 橋直方向 下: 橋軸方向 $)$

方により多少ばらつきがあるが，以下の解析では $\delta=5.9$ を 利用する. 補正結果を検証する方法としては，式(8)を利 用し変位計から傾斜角 $\theta$ を求めることができる. また, 変位計を 2 階微分寸れば真の加速度 $\ddot{x}$ を求めることがで きる.

まず，図-15に応答傾斜角と応答加速度を補正した時系 列波形をのせる．傾斜角の算出結果は，三つのセンサの 比較からは，概衫良好な結果を得ている，ただし，上り 列車において加速度計のみ零点がずれている結果となっ ている. これの原因としては, 加速度センサの低振動数 （0.2Hz 以下）の計測結果が温度特性等により不安定であ ることが挙げられる．また，傾斜計は前述したように粘 性等により次遅れがあるため, 図-16の波形において細か い応答（高振動数成分）が少ないことがわかる.

次に, 応答傾斜角と応答加速度を補正した後のスペク トルと変位計から求めた傾斜角および加速度のパワース ペクトルを比較したものが図-16である. 補正後の結果が 変位計のスペクトルと一致していることがわかる．また， 図-17には，全ての測定列車について，応答傾斜角および 応答加速度を式(8)を利用して変位換算した後の最大值と 変位計の值との関係を示した．橋直方向では, 両センサ 
ともに変位計との相関は高く, 橋軸方向は傾斜センサと の相関が特に高いことがわかる．なお，誤差に影響する 要因としては, 回転半径 $\delta$ の值が列車ごとに相違すると いった物理的な要因と, 特に加速度計では, 前述したよ うなセンサの温度特性等による計測誤差が混在している と考えられる．なお，変位が大きく出ているのは貨物列 車による応答である.

\section{6. 結論}

本研究における結論を以下に述べる.

・ 慣性計測において，今までは誤差として考えられてい た低振動数成分の応答について, 加速度センサの傾斜 および傾斜センサへの加速度を補正する理論を構築し た.

・補正に必要なパラメータが構造系を仮定することで定 義できることを示した.

- 実際の鉄道橋の橋脚で慣性計測(傾斜角, 加速度)を行 い, 固定計測が行える場合と, 慣性計測のみしか行え ない場合でパラメータの值を算出する方法を提案した. また，慣性計測で得た応答傾斜角と応答加速度に対し て, 同時に行った変位計との比較から補正手法の有効 性を示した.

なお本手法により得られた值の精度を検討するために は, 計測対象とする応答に対して, 利用寸るセンサの性 能を把握する必要がある. しかし，ヘルスモニタリング に利用するセンサの仕様は明確でなく, 特に, 実運用に おいて重要となる, 長周期域での自己ノイズの大きさ, 感度や零点の温度特性および長期特性の変化（長期而久 性）はメーカによって仕様化されていないのが現状であ る. ヘルスモニタリングのニーズに合わせたセンサ性能 の仕様化問題に関して現在研究を進めているところであ る.

\section{付録}

鉄道構造物の変位計測方法として古くから利用されて いるリング式変位計による計測結果を利用して橋脚の鉛 直変位 $V$ および水平変位 $X, Y$, また傾斜 $\theta$ を求める方法 を述べる. 変位計の設置は図-18のように橋脚天端 8 本と 橋脚首部 4 本の変位計を設置することで, 以下のように, 三方向の変位成分を抽出することができる. ただし，こ の場合は, 並進による変位とロッキング振動による変位 が混在することに注意が必要である．橋脚天端 8 本より
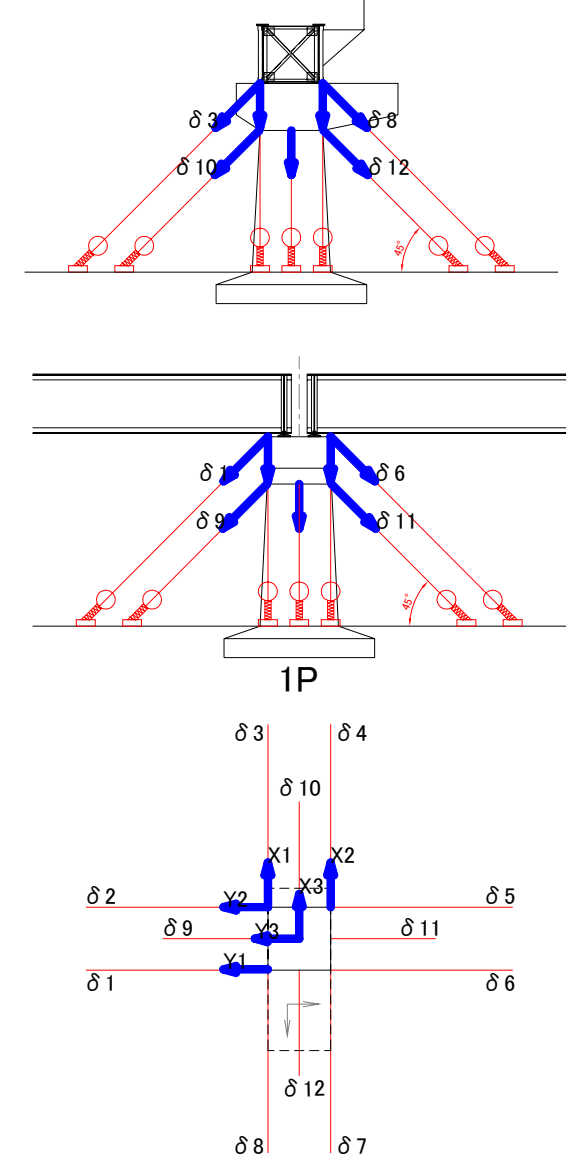

図-18 リング式変位計設置図

$$
\begin{gathered}
V_{X 1}=\frac{1}{2}\left(\frac{\delta 3}{\sin \varphi}+\frac{\delta 8}{\sin \varphi}\right), \quad V_{X 2}=\frac{1}{2}\left(\frac{\delta 4}{\sin \varphi}+\frac{\delta 7}{\sin \varphi}\right) \\
V_{Y 1}=\frac{1}{2}\left(\frac{\delta 1}{\sin \varphi}+\frac{\delta 6}{\sin \varphi}\right), \quad V_{Y 2}=\frac{1}{2}\left(\frac{\delta 2}{\sin \varphi}+\frac{\delta 5}{\sin \varphi}\right) \\
V_{X}=\frac{1}{2}\left(V_{X 1}+V_{X 2}\right), \quad V_{Y}=\frac{1}{2}\left(V_{Y 1}+V_{Y 2}\right) \\
X 1=(\delta 3 \cos \varphi-\delta 8 \cos \varphi) \\
X 2=(\delta 4 \cos \varphi-\delta 7 \cos \varphi) \\
Y 1=(\delta 1 \cos \varphi-\delta 6 \cos \varphi) \\
Y 2=(\delta 2 \cos \varphi-\delta 5 \cos \varphi)
\end{gathered}
$$

よって, 水平変位は

$$
X=\frac{1}{2}(X 1+X 2), \quad Y=\frac{1}{2}(Y 1+Y 2)
$$

となる.

また，ねじれは

$$
X_{T}=(X 1-X 2), \quad Y_{T}=(Y 1-Y 2)
$$

となる.

また，橋脚首部 4 本より

$$
V=\frac{1}{2}\left(\frac{\delta 9}{\sin \varphi}+\frac{\delta 11}{\sin \varphi}\right)=\frac{1}{2}\left(\frac{\delta 10}{\sin \varphi}+\frac{\delta 12}{\sin \varphi}\right)
$$




$$
\begin{gathered}
X=(\delta 10 \cos \varphi-\delta 12 \cos \varphi) \\
Y=(\delta 9 \cos \varphi-\delta 11 \cos \varphi)
\end{gathered}
$$

橋脚の倒れはロッキング中心から橋脚天端中央部までの 距離を $L$ とすれば,

$$
\theta_{X}=\frac{X}{L_{X}}, \quad \theta_{Y}=\frac{Y}{L_{Y}}
$$

で傾斜角を求めることができる.

\section{参考文献}

1）安藤繁, 田村陽介, 戸辺義人, 南正輝 : センサネッ トワーク技術, 東京電機大学出版, 2005.

2) Encyclopedia of Structural Health Monitoring, John Wiley \& Sons Inc., 2009.3

3) 恒國光義, Phan H.D. Quoc, 岡崎慎一郎, 西村次男, 加藤佳孝, 魚本健人 : コンクリート道路橋の健全度モ ニタリング・システムの開発, 都市基盤安全工学国際 研究センター, 2005.4

4) 石川裕治, 竹本健一, 宮崎早苗：リアルタイム橋梁 遠隔監視システムの開発，NTT 技術ジャーナル， 2006.9

5) 倉田成人：ユビキタス・センサネットワークの建 築・都市への応用，電子情報通信学会，2007.5

6) 杉崎光一, 増井洋介, 堀合聡, 阿部雅人, 阿部允, 島村誠：傾斜センサを用いた洗掘モニタリングシステ ムの開発，第 14 回鉄道力学シンポジウム, 2010.7

7) 阿部雅人, 藤野陽三 : 不規則振動理論を援用した加 速度記録からの地震時最大応答変位のリアルタイム推 定，土木学会論文集 A，Vol. 65，No.1， 2009.

8) 阿部雅人, 藤野陽三 : 不規則外力に対する加速度記 録からの最大応答変位推定, 土木学会論文集 $\mathrm{A}, \mathrm{Vol}$. 66, No. 3, pp.477-490, 2010.

9) 阿部允, 阿部雅人, 杉崎光一: 構造物維持管理マネ ジメントにおけるモニタリングのコンセプト, 第 7 回 構造物の安全性・信頼性に関する国内シンポジウム, 2011.10
10) 新谷昌人：やさしい地震計・加速度計, 地球の「流 れ」をみる衛星重力ミッション収録論文

11) 新谷昌人, 大久保修平, 大竹雄次 : 衛星重力ミッショ ン用加速度計開発の現状, 東京大学地震研究所, 精密 衛星測位 : 衛星重力観測による地球のダイナミクス研 究へのブレーク・スルー集録, Tokyo, 11-12 November 2003, pp.178-186, 2004.

12) 坂口貴司: 加速度センサとジャイロセンサを用いた屈 曲動作計測, 計測自動制御学会論文集, Vol.33, No.6, pp.455-460, 1997.6

13) 高原健爾, 大山和宏, 橋本幸男 : 微分フィルタを利用 した剛体の傾斜角計測システムの開発, 福岡工業大学 研究論集, Vol.39, No.2, 2007.

14) サーボ型加速度計出願番号 : 特許出願 2002-72673 出 願日, 2002 年 12 月 24 日株式会社アカシ外 1 名.

15) 武尾実 : 地動の回転成分を観測する新しい地震計の開 発, 東京大学地震研究所広報, No.26, 1999.9

16) 長井望, 三田彰, 矢向高弘, 佐藤忠信 : 構造ヘルスモ ニタリング用ワイヤレスセンサに関する研究, 日本地 震工学会論文集, 第 3 巻, 第 4 号, 2003.

17) 平田賢治, 川口勝義 : ケーブル式海底地震計の姿勢と 強震動, JAMSTEC 深海研究, 第 21 号, 2002.

18) 佐川貢一, 佐藤豊, 猪岡光 : 水平方向歩行距離の無拘 束計測, 計測自動制御学会論文集, Vol.36, No.11, pp.909-915， 2000.11

19) 鈴木崇伸，堀宗朗，壁谷澤寿海 : ジャイロセンサーに よる構造物の耐震性能モニタリング, 応用力学論文集, Vol.6, pp.747-754, 2003.8

20) 中村豊, 田母神宗之, 佐藤新二, 立花三裕 : 常時微動 を用いた新しい橋脚健全度評価法の提案, 鉄道総研報 告, Vol.8, No.5, pp.47-52, 1994.5

21) 土木学会構造工学研究会: 構造力学公式集, 土木学会, 1986.

(2011. 8. 22 受付)

\section{INCLINATION AND VIBRATION MEASUREMENT BY INERTIAL SENSING FOR STRUCTURAL HEALTH MONITORING}

\section{Koichi SUGISAKI, Masato ABE and Satoru KOSHIMIZU}

To develop a practical health monitoring system, inertial sensing which can readily be done for wide variety of situations is useful. However inertial sensors are measuring inclination and acceleration in reference to gravity. Therefore inclination are influence by acceleration and vice versa caused measuring errors. Especially, errors are more affected at low-frequency band which is important to estimate displacement. In this study, to establish correcting theory for inertial sensing and to develop method to estimate parameters for some structural system. And conducted a field test targeted at the real railway bridge to verify the effectiveness of the proposed method using response records of the pier under passing train load. 